ISSN 2078-6441. Вісник Львівського університету. Серія географічна. 2013. Випуск 41. С. 232-242.

Visnyk of the Lviv University. Series Geography. 2013. Issue 41. P. 232-242.

911.3 .33

\author{
( \\ иросл в етровськ, рин их йлів \\ ввівський н ціон льний університет імені в н \\ вул. . орошенк , 41, 79000, м. ьвів, кр їн
}

x p ктеризов но суч сну демогр фічну ситу цію еремишлянського р йону ( ьвівськ обл.). 'ясов но структуру господ рського комплексу і земельного фонду регіону. икон но інтегр льне оцінюв ння н пруженості геоекологічної ситу ції дміністр тивно-територі льних утворень досліджув ного р йону.

лючові слов : н селення, природний приріст, щільність н селення, господ рський комплекс, земельний фонд, геоекологічн ситу ція.

емельний фонд будь-якої території - це іiі основне б г тство і територі льн 63 для ведення господ рської діяльності. ст нніми рок ми посилення нтропогенного впливу н всі види природних ресурсів спричинює їхні серйозні зміни, які здебільшого є незворотними. ожн стверджув ти, що під впливом природокористув ння відбув ється з мін природних л ндш фтів нтропогенними. роблеми вивчення т н лізу цих змін є в жливою скл довою оптиміз ції і н л годження природокористув ння, т кож поліпшення відносин у системі людин -природне середовище.

еремишлянщин не н лежить до промислових р йонів ьвівщини, проте помітними є нтропогенні зміни в землекористув нні. ш мет - з'ясув ння поселенського н в нт ження, структури земельного фонду т оцінк ролі дест білізув льних чинників у меж х дміністр тивно-територі льних утворень досліджув ного р йону.

кожним роком н зв ні проблеми щор з більше з гострюються. собливо помітною ст л несприятлив екологічн ситу ція в меж х території поселень, що позн ч ється н системі демогр фічних пок зників, які зд тні ф ктично відобр зити рівень природного і суспільного бл гополуччя території.

кологічні проблеми, виникнення яких пов'яз не з існув нням поселень, трив лий ч с перебув ють у полі зору вчених-геогр фів: . р новського, . ороп й, . бч к, . ригор'євої, . уцуляк , . митрук , . с ченк , . ерничної, . ов льчук , . руглов , . руля, . руль, . убенко, . униці, . ург невич, . еліхової, . ельник , . лішевської, . вловської, . етровської, . илипович, . дикової, . ищенк т ін.

ивчення ст тистичних м тері лів ост ннього десятиріччя переконливо свідчить, що у ьвівській обл. $з$ г лом і в окремих їі р йон х зокрем, демогр фічн ситу ція змінил ся. ому про н лізуємо дет льніше поселенське н в нт ження і структуру земельного фонду еремишлянського р-ну ьвівської обл. т їхній вплив н формув ння геоекологічної ситу ції.

етровськ ., их йлів ., 2013 
еремишлянський р йон розт шов ний у південно-східній ч стині ьвівської обл. ін межує н півночі із олочівським р-ном, н північному з ході - устомитівським, н сході-з ернопільською обл., н півдні - 3 в но- $р$ нківською обл., н південному 3 ході-3 ид чівським, н 3 ході-3 икол ївським р йон ми.

осліджув ний р йон н лежить до регіонів, д вно освоєних людиною. першими письмовими зг дк ми, які орієнтовно визн ч ють ч с виникнення поселення, ми виділили: н йд вніші (XIII-XV ст.); середнього віку (XVI-XVIII ст.) і порівняно молоді (XIX ст.). йст рішим н селеним пунктом $є$ ібрк (1211), н ймолодшим - пильчин (1850) (рис. 1).

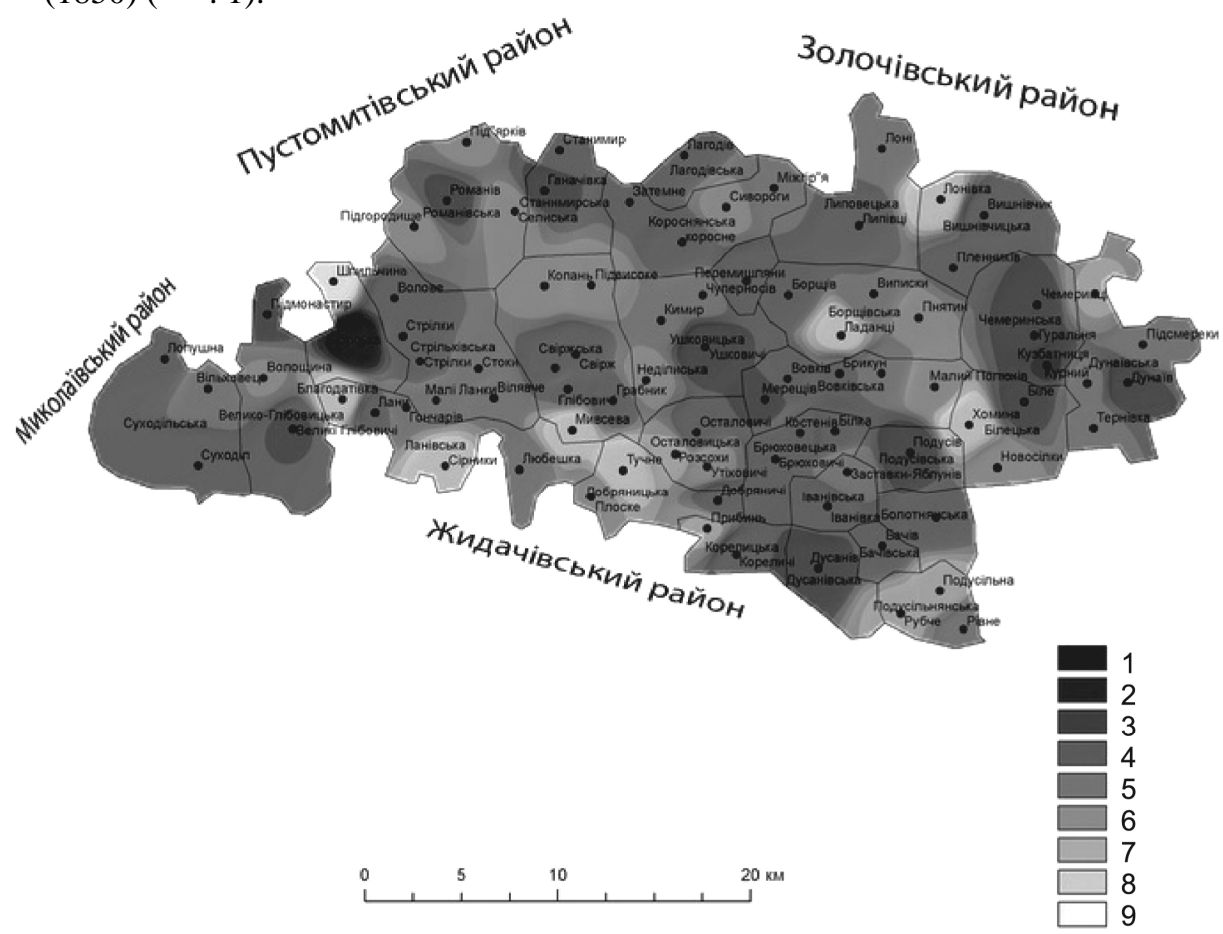

ис. 1. ерші писемні зг дки про поселення еремишлянського р-ну.

с $з$ селення території, роки: 1 - 1211-1275; 2 - 1276-1350; 3 - 1351-1425; 4 - 1426-1500; 5-1501-1575; 6 - 1576-1650; 7 - 1651-1725; 8-1726-1800; 9-1801-1875. кл дено з [3, 10].

т ном н 01.01.2010 р. кількість н явного н селення в еремишлянському р-ні ст новил 40,9 тис. осіб, з них міське н селення - 10,7, сільське - 30,2 тис. осіб. ротягом 19802010 рр. н селення р йону зменшув лося (60,0 і 40,9 тис. осіб, відповідно) (див. рис. 2).

оефіцієнт природного приросту в еремишлянському р-ні є від’ємним. окрем , у 2000 р. він ст новив $-8,9 \%$, до 2010 р. зріс до -9,7\%o. Йнижчий природний приріст простежено в 2005 р. (-10,8\%о) (див. рис. 3).

демогр фічний потенці л еремишлянського р-ну вплив є не лише природний приріст н селення, й різном нітні мігр ційні рухи. льдо мігр ції (різниця між прибулими т вибулими) в р йоні є від'ємним і ст новить -343 особи (-8,3\%o) для внутрішньорегіон льної і -103 особи (-2,4\%о) для зовнішньорегіон льної мігр ції (див. рис. 4). 


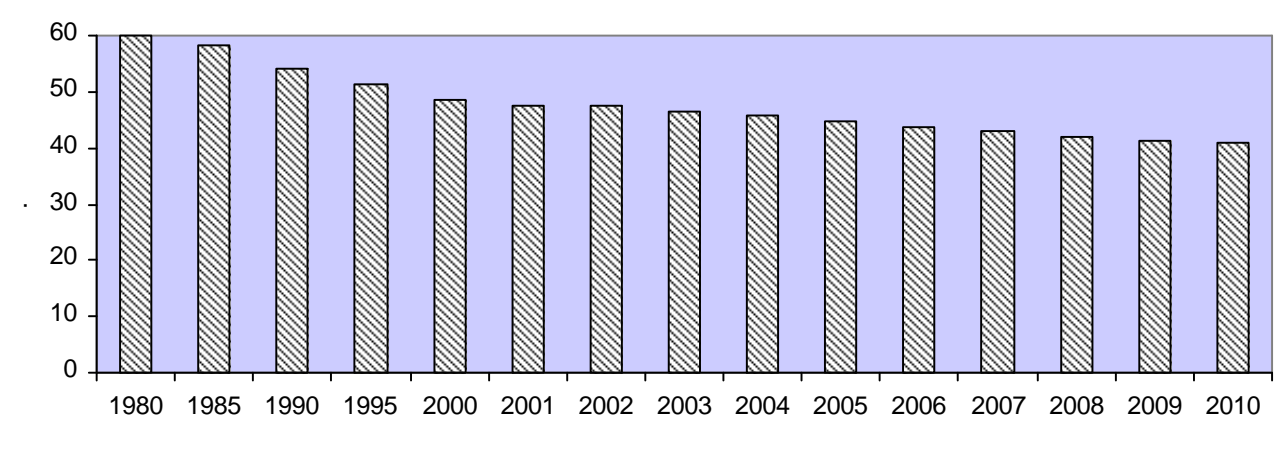

ис. 2. ин мік кількості н селення еремишлянського р-ну. кл дено з $[4,7]$.

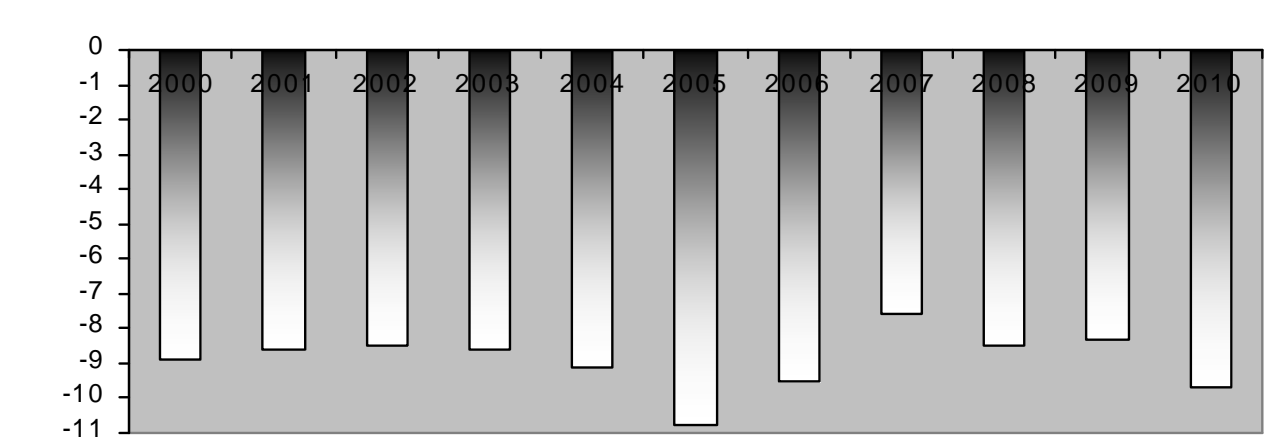

ис. 3. ин мік природного приростун селення еремишлянського р-ну. кл дено з $[4,7]$.

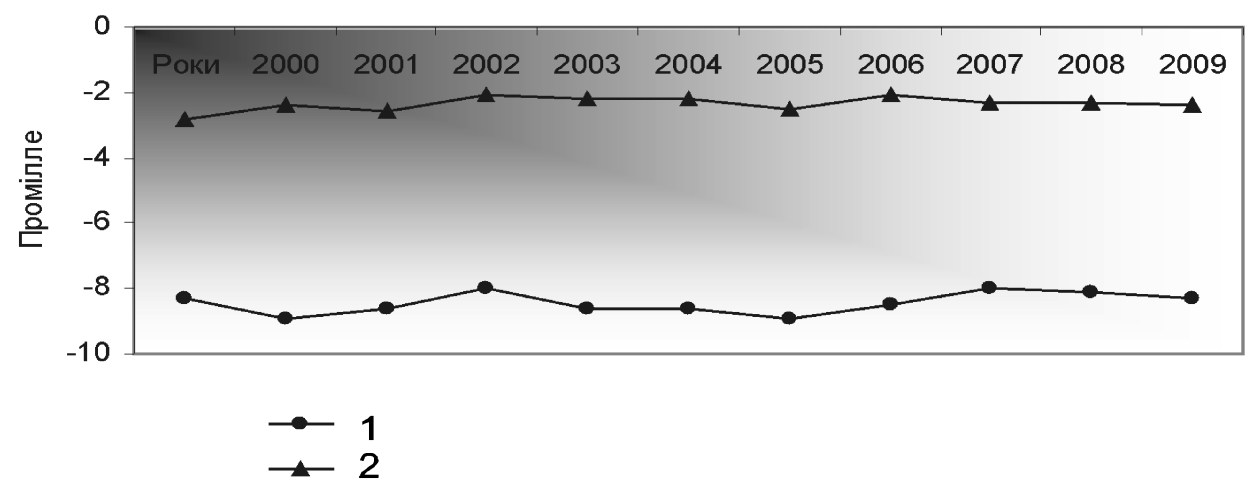

ис. 4. "ин мік мех нічного руху н селення "еремишлянського р-ну.

льдо мігр ції: 1 - внутрішньорегіон льне; 2 - зовнішньорегіон льне. кл дено 3 [4, 7]. 
ередня щільність н селення в еремишлянському р-ні ст новить 67 осіб/км². poте вон не є одн ковою по території р йону (рис. 5), що пояснюють розміщенням н селених пунктів і мех нічною мігр цією н селення з м лих сіл у більші й у міст .

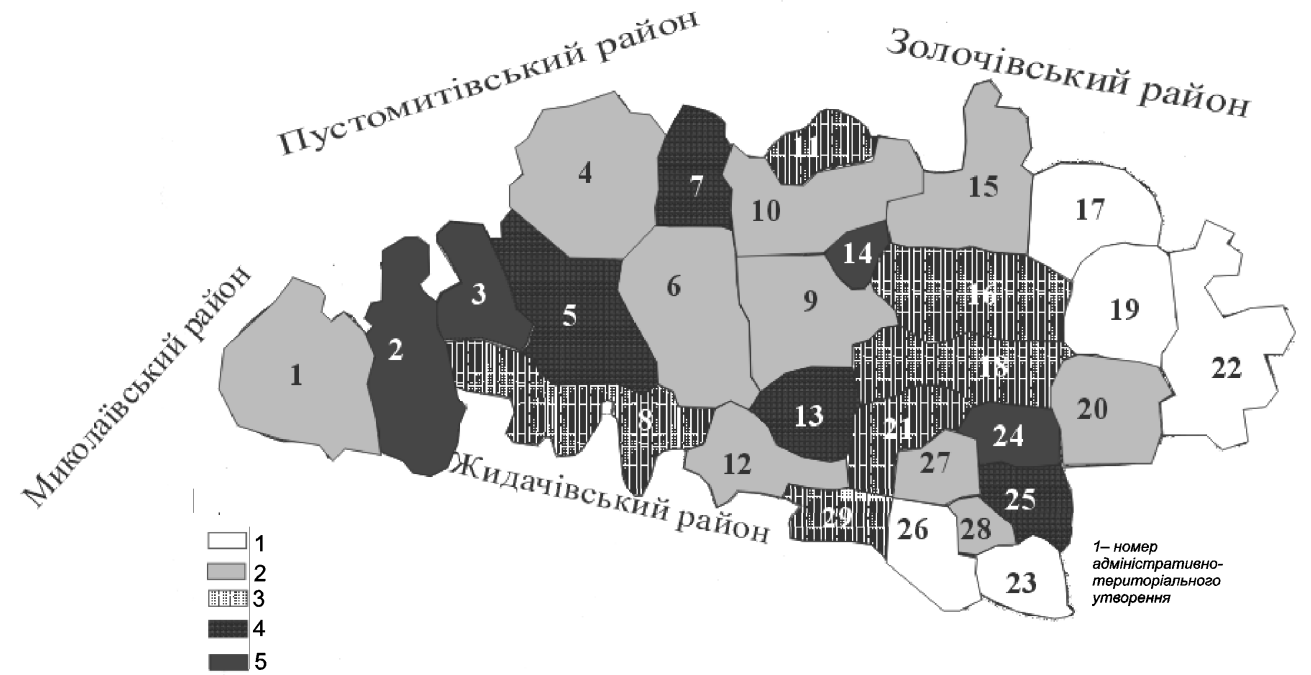

ис. 5. ільність н селення в еремишлянському р-ні ст ном н 01.01 .2010 р., осіб/км² 1 - 90-140; 2 - 140-190; 3-190-240; 4-240-290; 5->290. кл дено з [10]. ериторі льно- дміністр тивні утворення еремишлянського р-ну: 1, 2, 4-13, 15-29 - сільські р ди: 1 - уходільськ ; 2 - еликоглібовецьк ; 4- ом нівськ ; 5 - трілківськ ; 6 - віржськ ; 7 - т нимирськ ; 8 - нівськ ; 9 - шковичівськ ; 10 - оросненськ ; 11 - годівськ ; 12 - обряницьк ; 13 - ст ловицьк ; 15 - иповицьк ; 16 - орщівськ ; 17 - ишнівчицьк ; 18 - овківськ ; 19 - емеринецьк ; 20 - ілецьк ; 21 - рюховицьк ; 22 - ун ївськ ; 23 - одусільнянськ ; 24 - одусівськ ; 25 - олотнянськ ; 26 - ус нівськ ; 27 - в нівськ ; 28 - чівськ ;29- ореличівськ ; 3, 14- міст :3 - ібрк ; 14 - еремишляни.

йбільшу щільність н селення простежено у ібрській $(348$ осіб/км²) т еремишлянській (367 осіб/км²) міських р д х. он д 290 осіб/км² 2010 р. було у еликоглібовецькій т одусівській сільських р д х; 240-290 осіб/км² є у трілківській, т нимирській, ст ловицькій т олотнянській сільських р д х. нівськ, орелицьк, рюховецьк, овківськ, орщівськ і годівськ сільські р ди м ють щільність н селення 190-240 осіб/км². йбільше - десять сільських р д - м ють щільність н селення 140-190 осіб/км² ( уходільськ, ом нівськ, віржськ, ороснянськ, шковицьк , обряницьк, иповецьк, в нівськ, чівськ, ілецьк ).

йменш щільність н селення (90-140 осіб/км²) у ус нівській, одусільнянській, ишнівчицькій, емеринецькій і ун ївській сільських р д х.

еремишлянський р-н утворений у грудні 1939 р. 1962 р. його територія н леж л до скл ду олочівського р-ну, 04.01.1964 p. еремишлянський р йон відновлено в дещо змінених меж х. лощ дміністр тивного р йону з йм є 91,8 тис. г, що ст новить 4,2\% території ьвівщини. о еремишлянського р-ну віднесено 89 н селених пунктів, об’єдн них у 29 місцевих р д, з яких дві міські й 27 сільських [9]. 
ровідну роль у структурі господ рств р йону посід є сільське господ рство, н яке в сукупній в ловій продукції прип д є близько $75 \%$ (головне нтропогенне н в нт ження н природні комплекси р йону спричинене, н с мперед, впливом гр рного сегмент ), промисловості - близько $25 \%$. ктивний розвиток гропромислового комплексу в р йоні простежено у середині XX ст.

поч ток 2010 р. земельний фонд еремишлянського р-ну ст новив 91,79 тис. г , 3 яких 59,2 тис. г з йм ють сільськогоспод рські землі (64,4\% від з г льної площі); 28,71 - ліси т лісовкриті площі $(31,3) ; 2,6$ - з будов ні землі $(2,8) ; 0,8$ тис. г - землі під водою $(0,8 \%)$. середньому н одного мешк нця еремишляншини прип д є 2,24 г земельного фонду (для порівняння: в кр їні-1,25 г ; у ьвівській обл. $-0,86$ г ).

Розподіл сільськогосподарських земель на території району в межах адміністративно-територіальних утворень відображено на рис. 6.

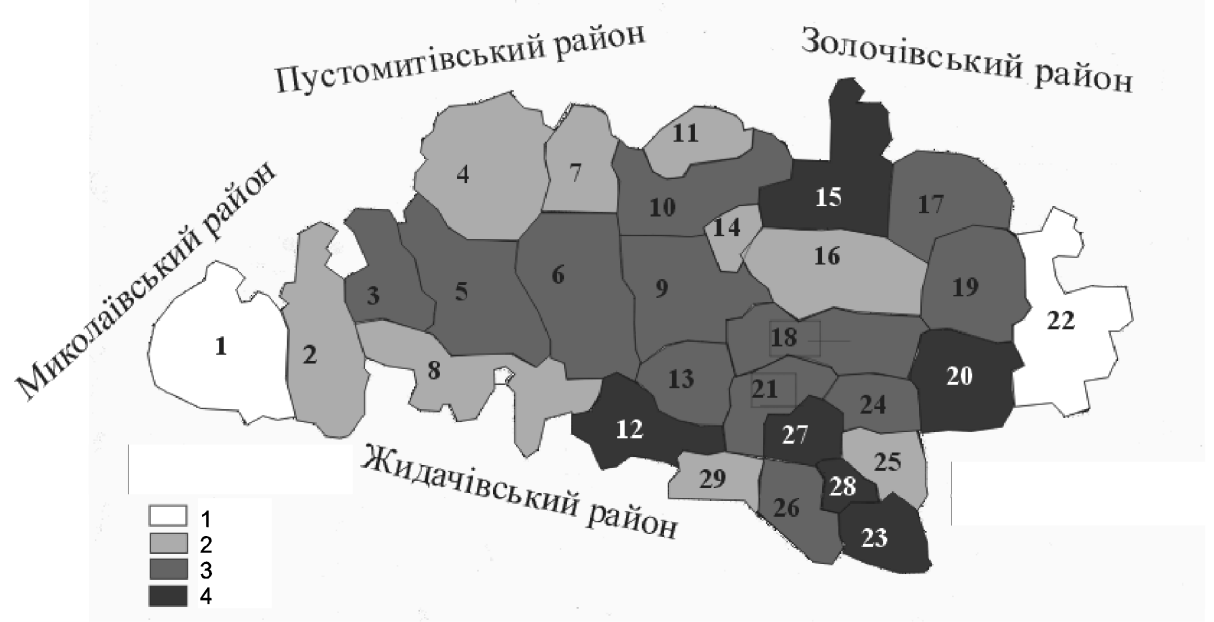

ис. 6. стк площі дміністр тивно-територі льних утворень еремишлянського р-ну, 3 йнят сільськогоспод рськими землями ст ном н 01.01.2010 р., \%: 1 - <40; 2-41-60; $3-61-80 ; 4->80$. ифр ми позн чено (див. рис. 5). кл дено з [8].

о сільськогоспод рських угідь н леж ть рілля, 6 г торічні н с дження, сінож ті т п совищ . усієї площі сільськогоспод рських угідь (59,2 тис. г ) н ріллю прип д $є$ 39,34 тис. г (66,5 \% від площі сільськогоспод рських угідь), н 6 г торічні н с дження $-1,1(1,8)$, н сінож ті - 5,6 $(9,6)$, н п совищ $-11,8$ тис. г $(19,9 \%)$. одну людину в еремишлянському р-ні прип д є 1,44 г сільськогоспод рських земель і 0,96 г ріллі (для порівняння: в кр їні - 0,89 і 0,68 г ; у ьвівській обл. - 0,50 і 0,31 г ).

тупінь розор ності земель х р ктеризує іхню екологічну стійкість. йбільш екологічно нестійкими є ті р йони, у яких розор ні землі зн чно перев ж ють н д умовно ст більними угіддями, до яких н леж ть сінож ті, п совищ, землі, вкриті лісом, ч г рником, болот [2]. йонув ння еремишлянського р-ну з стійкістю земельних угідь пок 3 но н рис. 7, де пок зник стійкості відповід є відношенню площі умовно ст більних угідь до площі ріллі. г лом коефіцієнт екологічної стійкості для еремишлянського р-ну ст новить 1,17 . 
структурі посівних площ р йону перев ж ють зернові культури. 2010 р. всім к тегоріями господ рств зібр но 8450 г зернових культур і н молочено 23680 т зерн . рож йність ст новить 27,9 ц 31 г. укрові буряки викоп но н площі 230 г, зібр но 10 тис. т буряків з врож йності 430 ц з 1 г . ібр но к ртоплю з 3250 г і овочі з 609 г , виробництво яких, відповідно, ст новить 50,2 і 10,0 тис. т.

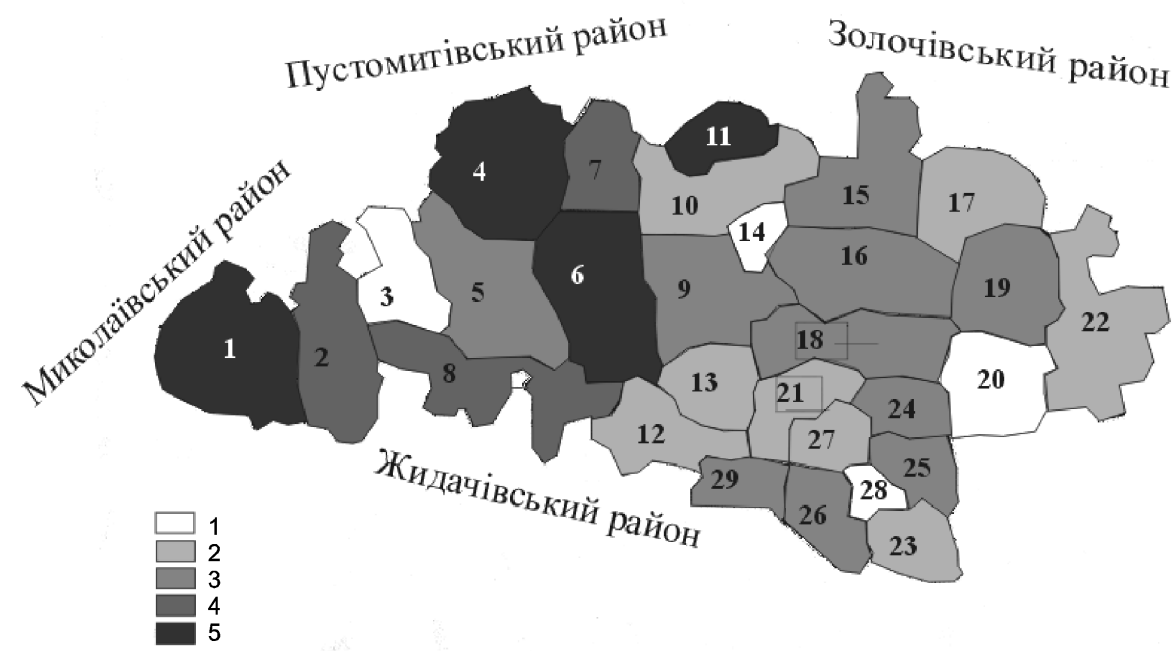

ис. 7. тупінь екологічної стійкості земельних угідь еремишлянського р-ну: $1-0,1-0,5$; $2-0,51-0,9 ; 3-0,91-1,3 ; 4-1,31-1,7 ; 5->1,7$. ифр ми позн чено (див. рис. 5). кл дено 3 [8].

оз обробітком з лиш ється 19,5 тис. г , бо 51,3\% ріллі, у тім числі цілин і перелоги $-7,9$ тис. г , вип с ння худоби $-8,1$, с моз ліснено - 3,5 тис. г .

ільськогоспод рським виробництвом у 2010 р. 3 йм лися 16 сільськогоспод рських підприємств, 16 фермерських господ рств і 11,7 тис. індивіду льних прив тних господ рств. итом в г виробництв в лової продукції в сільськогоспод рських підприємств х у з г льному обсязі ст новить 9,3\%, господ рств н селення - 90,7\%.

ісовий фонд еремишлянського р-ну ст ном н 01.01 .2010 р. ст новив 28,71 тис. г . озподіл лісів і лісовкритих площ р йону зобр жено н рис. 8.

p йоні перев ж ють ліси першої групи - 15,98 тис. г (55,6 \% від усієї площі лісів), ліси другої групи є н площі 12,6 тис. г (44,4\%). одного мешк нця р йону прип д є 0,7 г , вкритої лісом площі. е зн чно більше, ніж н одного мешк нця кр їни і ьвівської обл. (0,17 і 0,24 г , відповідно).

будов ні землі з йм ють 2,6 тис. г , бо 2,83\% від усіх земель еремишлянського р-ну. цій к тегорії перев ж ють землі під житловою з будовою - 0,74 тис. г (28,4 \% від з будов них земель), під промисловою з йнято 0,08 тис. г $(3,1 \%)$.

одні ресурси еремишлянського р-ну розміщені нерівномірно (див. рис. 9). лощ , $з$ йнят внутрішніми вод ми, ст новить 0,86 тис. г $(0,93 \%)$. ут перев ж ють м лі річки. олот з йм ють 64,13 г і є низинними.

ідкриті землі без рослинного покриву бо з незн чним рослинним покривом ст новлять 307,66 г . 


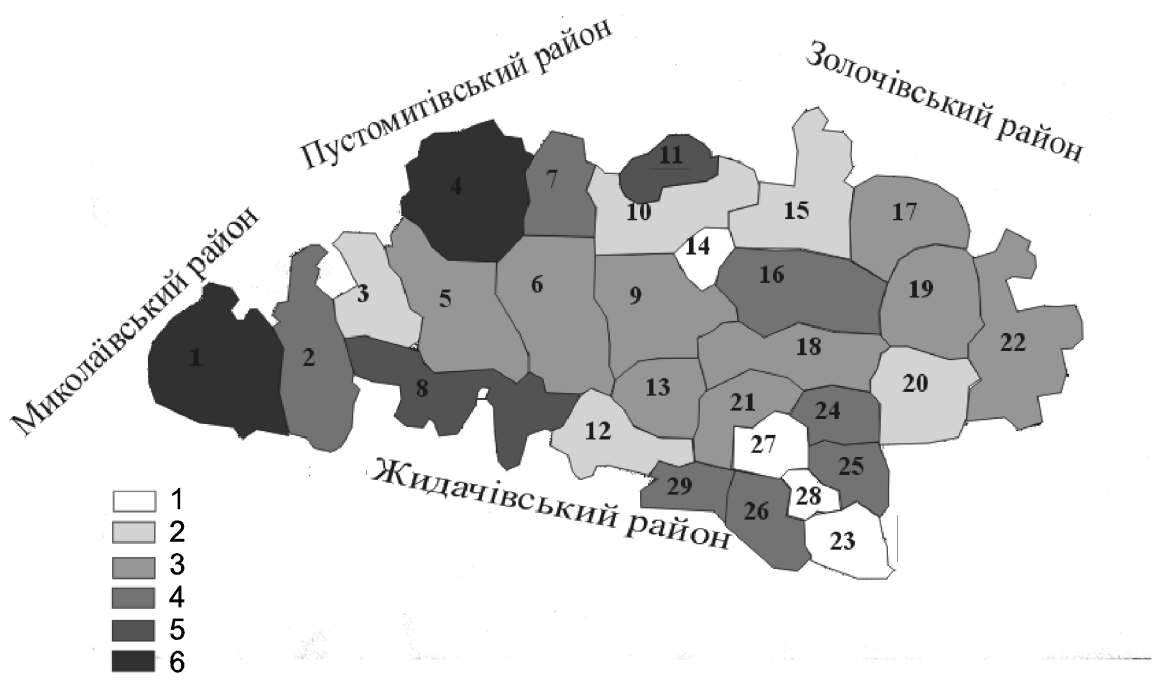

ис. 8. стк площі дміністр тивно-територі льних утворень еремишлянського р-ну, з йнят ліс ми т іншими лісовкритими площ ми ст ном н 01.01 .2010 р., \%: $1-<10 ; 2-11-20$; $3-21-30 ; 4-31-40 ; 5-41-50 ; 6->50$. ифр ми позн чено (див. рис. 5). кл дено 3 [8].

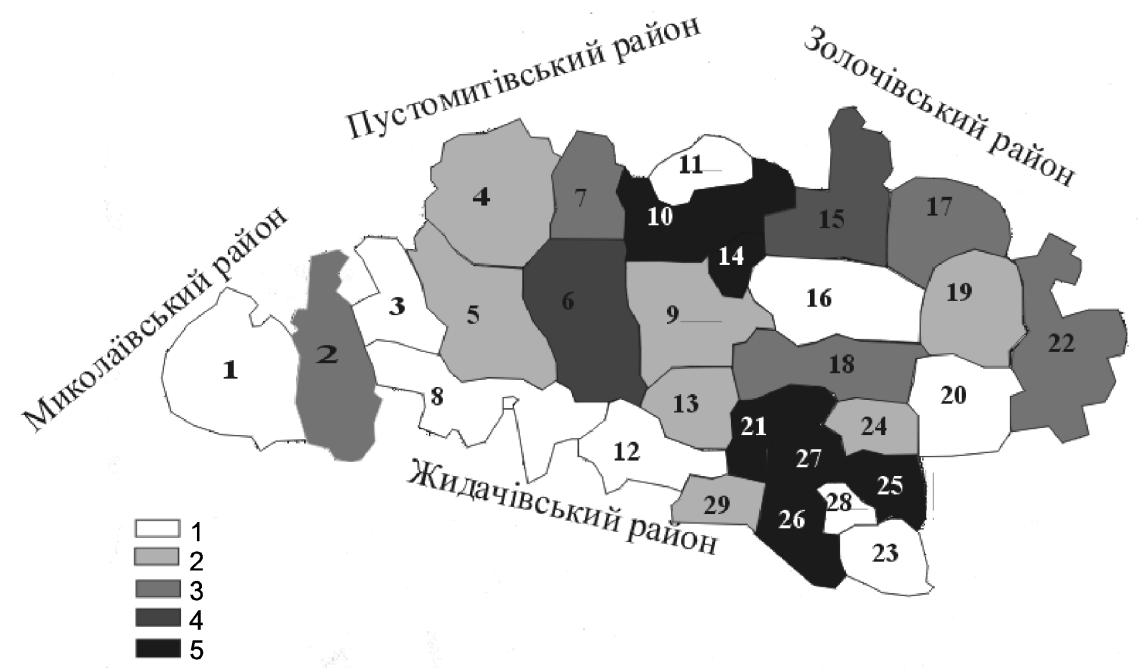

ис. 9. стк площі дміністр тивно-територі льних утворень еремишлянського р-ну, з йнят внутрішніми вод ми ст ном н 01.01 .2010 р., \%: $1-<0,6 ; 2-0,61-0,9 ; 3-0,91-1,2$;

$4-1,21-1,5 ; 5->1,5$. ифр ми позн чено (див. рис. 5). кл дено 3 [8].

еремишлянському р-ні зосереджено різном нітні природні ресурси, т кож н явні історико-культурні об'єкти. цінки природно-ресурсного потенці лу свідч ть про домінув ння земельних ресурсів - 44,3\%, т кож природно-рекре ційних - 19,3, водних $-19,1$, лісових - 13,9, мінер льних - 2,8\% [6]. 
ерев ж ючими ресурс ми у з безпеченості н селення є лісові - 282 б ли. безпеченість н селення водними ресурс ми - 123 б ли - сприяє розвитку рекре ційної г лузі [6]. исленні озер, ст вки, мисливські угіддя д ють змогу розвив ти мисливство т риб льство. території еремишлянського р йону функціонують декільк б $з$ відпочинку й оздоровчих т борів (“ злісся”, “ іпище”).

ум рний 6 л з безпечення природно-ресурсним потенці лом н селення еремишлянського р-ну в розр хунку н одну особу ст новить 84 (для порівняння, по ьвівській обл. - 72).

риродоохоронні об'єкти з йм ють лише 934,55 г (1,01\%), що є недост тнім, оскільки вони слугують не лише цілям охорони, й рекре ції, туризму, естетичному вихов нню і зрост нню з цік вленості екологічними проблем ми серед н селення.

одо порушених земель, то н йбільш їхня площ в р йоні з фіксов н 1990 р. 228 г . о 2005 р. вон суттєво зменшил ся (75 г), в 2007-2010 рр. бул незмінНОю -83 г.

ксим льну площу відпр цьов них земель простежено т кож у 1990 р. - 51 г .

н логічно, як і з порушеними землями, н 2000 р. їхня площ зменшил ся до 16 г , протягом 2005-2010 рр. не змінюв л ся (24 г).

йон 3 йм є не дуже вигідне тр нспортно-геогр фічне положення. емлі тр нспорту і зв'язку охоплюють у р йоні 630,18 г (0,68 \% від усієї площі р йону). лізничн мереж ч стково з безпечує зв'язок з обл сним центром і водноч с потребує реконструкції, зниження небезпеки в рій, з безпечення моніторингу ст ну полотн доріг і л лізничних н сипів.

сновні господ рсько-тр нспортні перевезення виконують втомобільним тр нспортом. $\quad$ йоні дост тньо розвинут мереж доріг з твердим покриттям. г льн протяжність доріг ст новить близько 370 км, з них 77,5 км 3 сф льтобетонним покриттям, зокрем , т кі втомобільні шляхи, як уровичі- ук чеве, еремишляни- ереж ни. оловними підприємств ми-з бруднюв ч ми в еремишлянському р-ні $є$ еремишлянський прил добудівний з вод “ одуль” (виробництво друков них пл т); олективне підприємство “ еблевик” (виробництво меблів, деревообробк ); еликоглібовецький деревообробний з вод; “ лектроконт кт кр їн ” (виробник електричних к бельних мереж); “ “ олісинтез” (виробляє пінополіурет н ел стичний (поролон)).

и викон ли інтегр льне оцінюв ння н пруженості геоекологічної ситу ції для території сільських р д. ля цього споч тку визн чили спектр чинників техногенного впливу н компоненти довкілля, серед яких - рілля, б г торічні н с дження, сінож ті, п совищ , сільськогоспод рські будівлі, сільськогоспод рські шляхи, житлов 3 будов , землі промисловості, землі комерційного і гром дського користув ння, ктивні торфорозробки, ктивні к р'єри і ш хти, відпр цьов ні торфорозробки, к р’єри і ш хти, втошляхи, з лізниці, інженерно-технічн інфр структур , землі для відпочинку, к м’янисті землі, піщ ні землі т яри. отім обчислили ч стку площі дміністр тивнотериторі льних утворень, н якій діють ці чинники. трим ну систему пок зників згрупув ли 3 п’ятиб льною шк лою. оль кожного пок зник уточнили множенням 6 льної оцінки цих чинників н коефіцієнт сили його впливу н екологічну ситу цію. оефіцієнт сили впливу визн чено методом експертних оцінок у меж х від 1,0 до 2,0. ум б льних оцінок кожного дест білізув льного чинник розр хов но для кожного 3 дміністр тивно-територі льних утворень досліджув ного регіону і використ но як інтегр льний пок зник екологічного н пруження. 
цінк ролі дест білізув льних чинників у меж х дміністр тивно-територі льних утворень еремишлянського р-ну д л змогу виділити р йони з дещо сприятливою, 3 довільною т н пруженою геоекоситу ціями (рис. 10).

ещо сприятливу геоекологічну ситу цію простежено в т ких сільських р д х: ходільськ, ом нівськ, т нимирськ, нівськ, віржськ, ишнівчицьк, ус нівськ, одусівськ, оросненськ . пружен ситу ція $€$ в дміністр тивнотериторі льних утвореннях: ібрськ, трілківськ, рюховецьк т еремишлянськ сільські р ди. решті сільських р д геоекоситу ція з довільн . ризової т сприятливої геоекологічної ситу ції не з фіксов но.

тже, еремишлянський р-н д вно освоєний людиною (перші поселення виникли у XIII ст.). т ном н 01.01.2010 р. кількість н селення в р-ні ст новил 40,9 тис. осіб, 3 них міське н селення - 10,7, сільське - 30,2 тис. осіб.

риродний приріст н селення у 2010 р. був від'ємним $(-9,7 \%$ \%).

ередня щільність н селення у еремишлянському р-ні ст новить 67 осіб/км². йбільш щільність простежен у ібрській $(348$ осіб/км²) $\mathrm{T}$ еремишлянській (367 осіб/км²) міських р д х.

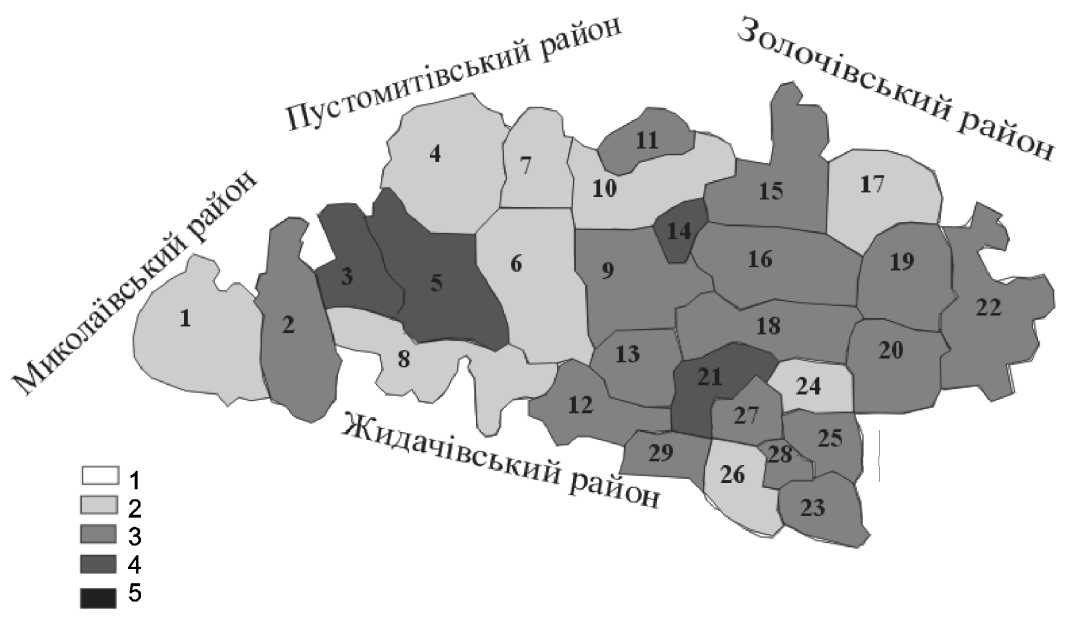

ис. 10. нтегр льне оцінюв ння н пруження геоекологічної ситу ції дміністр тивнотериторі льних утворень еремишлянського р-ну ст ном н 01.01.2010 р., б ли:

1 - <25 (сприятлив ); 2 - 25-40 (дещо сприятлив ); 3 - 41-55 (з довільн ); 4 - 56-70 (н пружен ); 5->70 (кризов ). ифр ми позн чено (див. рис. 5). кл дено 3 [8].

лощ дміністр тивного р йону з йм є 91,8 тис. г, що ст новить 4,2\% території ьвівщини. о еремишлянського р-ну н леж ть 89 н селених пунктів, об'єдн них у 29 місцевих р д, з яких дві міські і 27 сільських.

ровідну роль у структурі господ рств р йону відігр є сільське господ рство, н яке в сукупній в ловій продукції прип д є близько $75 \%$, чому сприяють великі площі, 3 йняті під сільськогоспод рські угіддя (64,4 \% від з г льної площі р йону). середньому н одного мешк нця еремишлянщини прип д $є 2,24$ г земельного фонду, 1,44 г сільськогоспод рських земель і 0,96 г ріллі. оефіцієнт екологічної стійкості земельних угідь ст новить 1,17 . 
цінк ролі дест білізув льних чинників у меж х дміністр тивно-територі льних утворень еремишлянського р-ну д л змогу виділити р йони з дещо сприятливою, з довільною т н пруженою геоекоситу ціями.

ізном нітність природних умов, н явність екскурсійних м ршрутів, історикокультурних об'єктів т певн інфр структур д ють змогу визн ти перспективною рекре ційно-туристичну г лузь.

\section{СПИСОК ВИКОРИСТАНОЇ ЛІТЕРАТУРИ}

1. овкілля ьвівщини: ст тистичний збірник. - ьвів : оловне упр вління ст тистики у ьвові, 2011.

2. емельні ресурси кр їни / з ред. . . едведєв , . . . ктіонової. - . : гр рн н ук , 1998. - 150 с.

3. стория городов и сел ьвовск я обл сть / под ред. . . ул ковского. иев : н-т истории , 1978. - 795 с.

4. ількість н селення ьвівської обл сті: ст тистичний збірник. - ьвів : оловне упр вління ст тистики у ьвівській обл сті, 2009; 2011.

5. ов льчук . . еоекологія озточчя / . . ов льчук, . . етровськ . - ьвів : ид вничий центр ім. в н р нк , 2003. - 192 с.

6. уденко . . еогр фія природно-ресурсного потенці лу кр їни : у 3 ч. : підручник. - ернівці : ернівецький н ціон льний університет, 2010. - 552 с.

7. т тистичні д ні по ьвівській обл сті. ин мік н селення 1980-2007 рр.: ст тист. зб. - ьвів, 2008.

8. орм № 6-зем. віт про н явність земель т розподіл їх з вл сник ми землі, землекористув ч ми, угіддями т вид ми економічної діяльності.

9. ікіпедія [ лектронний ресурс]. - ежим доступу: http://uk.wikipedia.org/

10. егіони кр їни т їх скл д [ лектронний ресурс]. - ежим доступу: http://gska2.rada.gov.ua/ 


\title{
SETTLEMENT PRESSURE AND STRUCTURE OF THE LAND RESOURCES OF PEREMYSHLYANY DISTRICT (LVIV REGION) AS A FACTOR OF FORMATION OF GEOECOLOGICAL SITUATION
}

\author{
Myroslava Petrovska, Iryna Mykhayliv \\ Ivan Franko National University of Lviv, \\ P. Doroshenko St., 41, UA-79000 Lviv, Ukraine
}

The modern demographic situation of Peremyshlyany district (Lviv region) has been described. The structure of the economic complex and of the land resources of the region has been found out. The integral evaluation of pressure of geoecological situation of administrative-territorial formations of the local district has been carried out.

Key words: population, natural increment, density of population, economic complex, fund of land, geoecological situation.

\author{
( \\ иросл в етровск я, рин ых йлив \\ ьвовский н цион льный университет имени вн \\ ул. . орошенко, 41, 79000, г. ьвов, кр ин
}

х р ктеризов но современную демогр фическую ситу цию еремышлянского р-н ( ьвовск я обл.). ыяснено структуру хозяйственного комплекс и земельного фонд регион . ыполнено интегр льную оценку н пряженности геоэкологической ситу ции дминистр тивнотерритори льных единиц исследуемого р йон .

лючевые слов : н селение, естественный прирост, плотность н селения, хозяйственный комплекс, земельный фонд, геоэкологическ я ситу ция. 